Chemistry - Separation Processes for Plutonium and Uranium AEC Research and Development Report
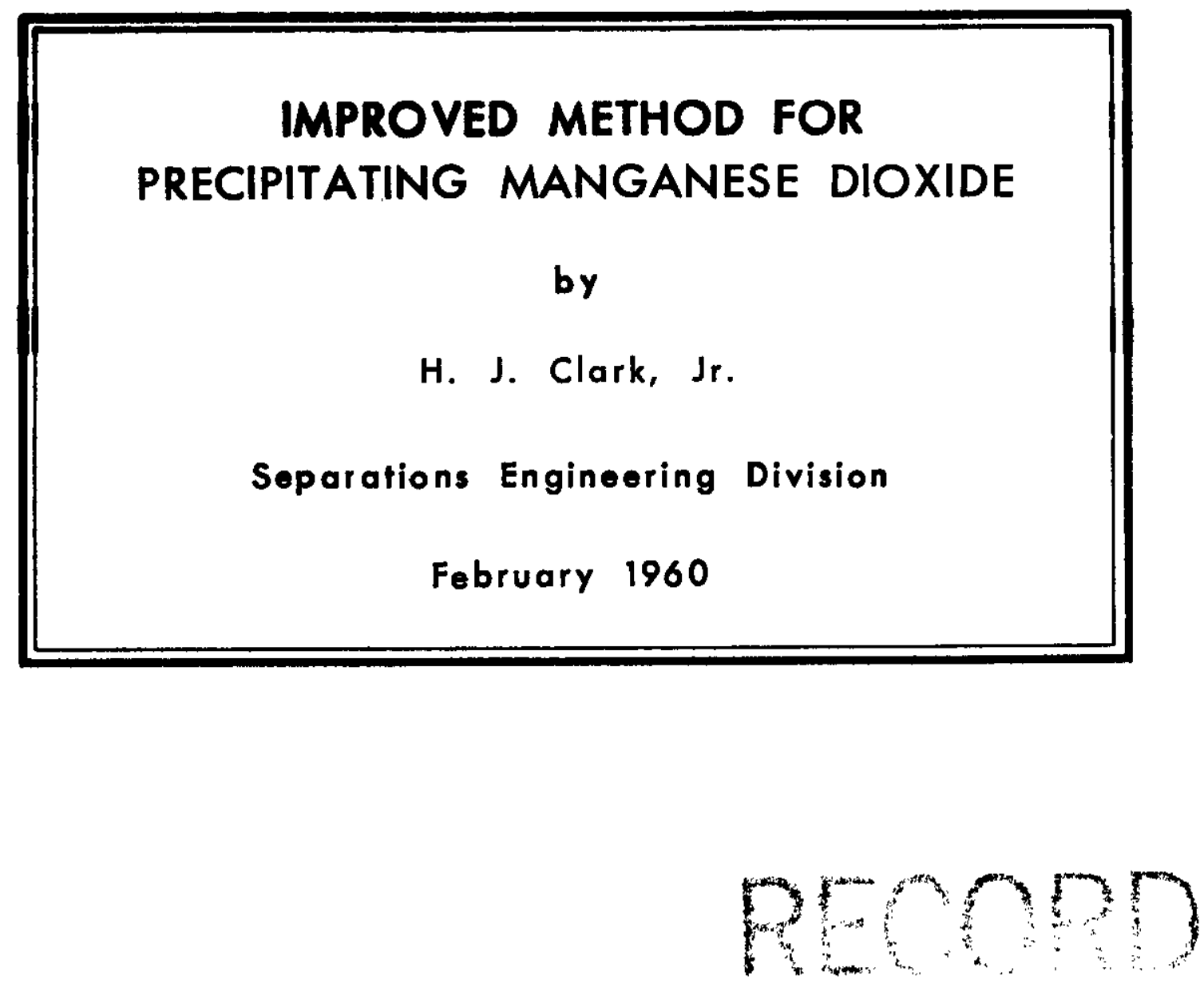

E. I. du Pont de Nemours \& Co. Savannah River Laboratory

Aiken, South Carolina 
Th1s report was prepared as an account of Government sponsored work. Ne1ther the United States, nor the Commission, nor any person acting on behalf of the Commission:

A. Makes any warranty or representation, expressed or implied, with respect to the accuracy, completeness, or usefulness of the information contained in this report, or that the use of any information, apparatus, method, or process disclosed in this report may not infringe privately owned rights; or

B. Assumes any llabilities with respect to the use of, or for damages resulting from the use of any information, apparatus, method, or process disclosed in this report.

As used in the above, "person acting on behalf of the Commission" Includes any employee or contractor of the Commission, or employee of such contractor, to the extent that such employee or contractor of the Commission, or employee of such contractor prepares, disseminates, or provides access to, any information pursuant to his employment or contract with the Commission, or his employment with such contractor.

Printed in USA. Price $\$ 0.50$

Avallable from the office of Technical Services

U. S. Department of Commerce Washington 25, D. C. 


$$
D P-444
$$

CHEMISTRY - SEPARATION PROCESSES

FOR PLUTONIUM AND URANIUM

(TID-4500, 15th Ed.)

\section{IMPROVED METHOD FOR PRECIPITATING MANGANESE DIOXIDE}

by

Harold J. Clark, Jr.

Work done by

V. P. Caracc1olo H. J. Clark, Jr.

J. F. Ward, Jr.

February 1960

E. I. du Pont de Nemours \& Co.

Explosives Department - Atomic Energy Division

Technical Division - Savannah River Laboratory

Printed for

The United States Atomic Energy Commission

Contract AT $(07-2)-1$ 


\section{ABSTRACT}

An improved method for precipitating manganese dioxide was demonstrated that significantly increases the allowable feed rate of the Purex head end centrifuge. The effects of several process variables are discussed. 


\section{CONTENTS}

$\underline{\text { Page }}$

Introduction

4

Summary

4

Discussion

Equipment

Procedure

Experimental Results

Bibliography

Append1x

Semiworks Results of Reverse Strike Head End Runs

\section{LIST OF FIGURES}

\section{Figure}

1 Approximate Arrangement of Sem1works Head End Test Equipment

2 Deta1ls of the Agltator in the Strike Tank

3 Mockup of Waste Header

4 Effect of Agitator Speed and $\mathrm{KMNO}_{4}$ Addition Rate on Cake Volume

5 Effect of Acid, Temperature, and UNH on Cake Volume

6 Effectiveness of Washing 


\section{IMPROVED METHOD FOR PRECIPITATING MANGANESE DIOXIDE}

\section{INTRODUCTION}

A "head end" or feed preparation step is used prior to solvent extraction in the Purex process to remove 60-80\% of the fission product activity that accompanies the uranium and plutonium and to remove any particulate matter that would interfere with solvent extraction. The commonly used head end process consists of the formation of a precipitate of manganese dioxide followed by the removal of this precipitate by centrifugation. In this application it is desirable that the precipitate be formed by adding potassium permanganate to a solution to which an excess of manganous nitrate has previously been added.

Previous work at SRL (1) satisfactorily demonstrated on a large scale a procedure for producing the manganese dioxide precipitate and showed the effectiveness of a solid bowl centrifuge for removing this precipitate from the solution.

Subsequent small-scale investigations in the laboratory (2) showed that vigorous agitation of the reactant materials during precipitation reduced the bulk volume of the manganese dioxide. This report covers semiworks studies to determine the feasibility of producing the more dense precipitate in large equipment and to confirm the centrifuging characteristics of the precipitate.

\section{SUMMARY}

An improved method for precipitation of manganese dioxide was demonstrated in plant-scale equipment and was shown to increase the processing capacity of the Purex head end step significantly. The equipment modifications to produce this precipitate were; 1) a shroud mounted around the upper of two paddles in the preclpitation tank, 2) a line to feed potassium permanganate solution into the shroud, and 3) an increase in the agitator speed. The results obtained are summarized below:

1. The precipitate could be centrifuged at five times the rate that could be obtained with the precipitate formed by the older method $^{(1)}$.

2. The precipitate formed at $160^{\circ} \mathrm{F}$ by the new method could be centrifuged as readily as that produced at $190^{\circ} \mathrm{F}$. Operation at lower temperatures is desirable to reduce volatilization of ruthenium.

3. The total capacity of the centrifuge bowl was increased as a result of the increase in precipitate density, and the resulting cake could be washed more efficlently. Three cake washes were necessary for a cake of normal size; five washes were necessary when the size of the cake was doubled. 
4. The cake was readily slurried from the centrifuge bowl and remained in suspension while the slurry was discharged through piping that simulated a waste disposal header.

\section{DISCUSSION}

\section{EQUIPMENT}

The semiworks installation, Figure 1, consists of a solid bowl centrifuge piped to existing tanks to make a complete system. Details regarding the equipment may be found in a previous report $(2)$. The modifications made to the equipment previously described were the addition of a shroud around the top paddle of the agitator and a feed line for $\mathrm{KMnO}_{4}$ solution leading into the shroud. These modifications are shown in Figure 2. The hydraulic-pneumatic skimmer system was replaced with a manual skimmer to facliltate "cold" operations. Varlous jet changes were made as necessary to change feed rates. Modifications were made so that the agitator speed could be increased to $130 \mathrm{rpm}$. Previous studies had been made at $84 \mathrm{rpm}$.

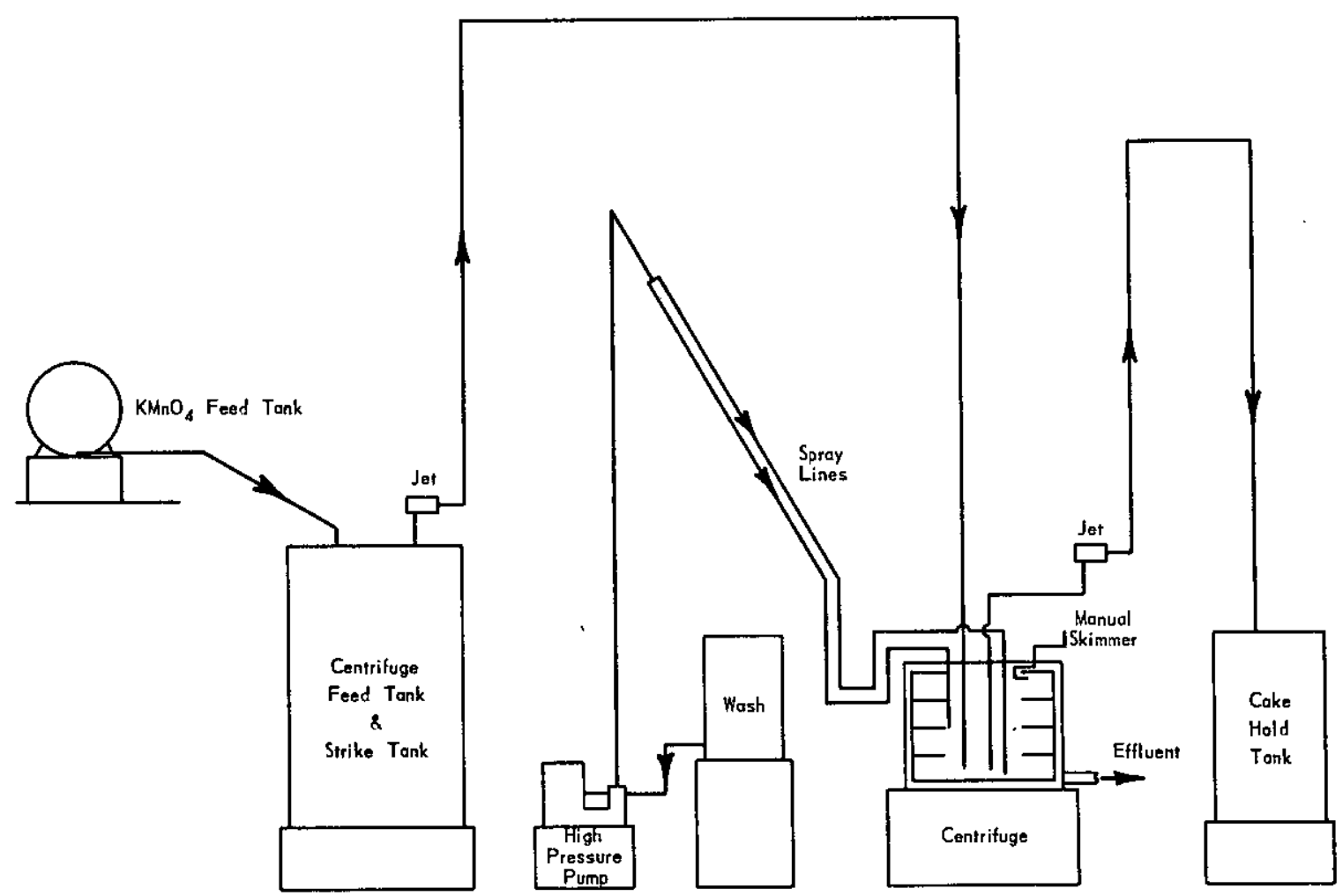

FIGURE I - APPROXIMATE ARRANGEMENT OF SEMIWORKS HEAD END TEST EQUIPMENT 


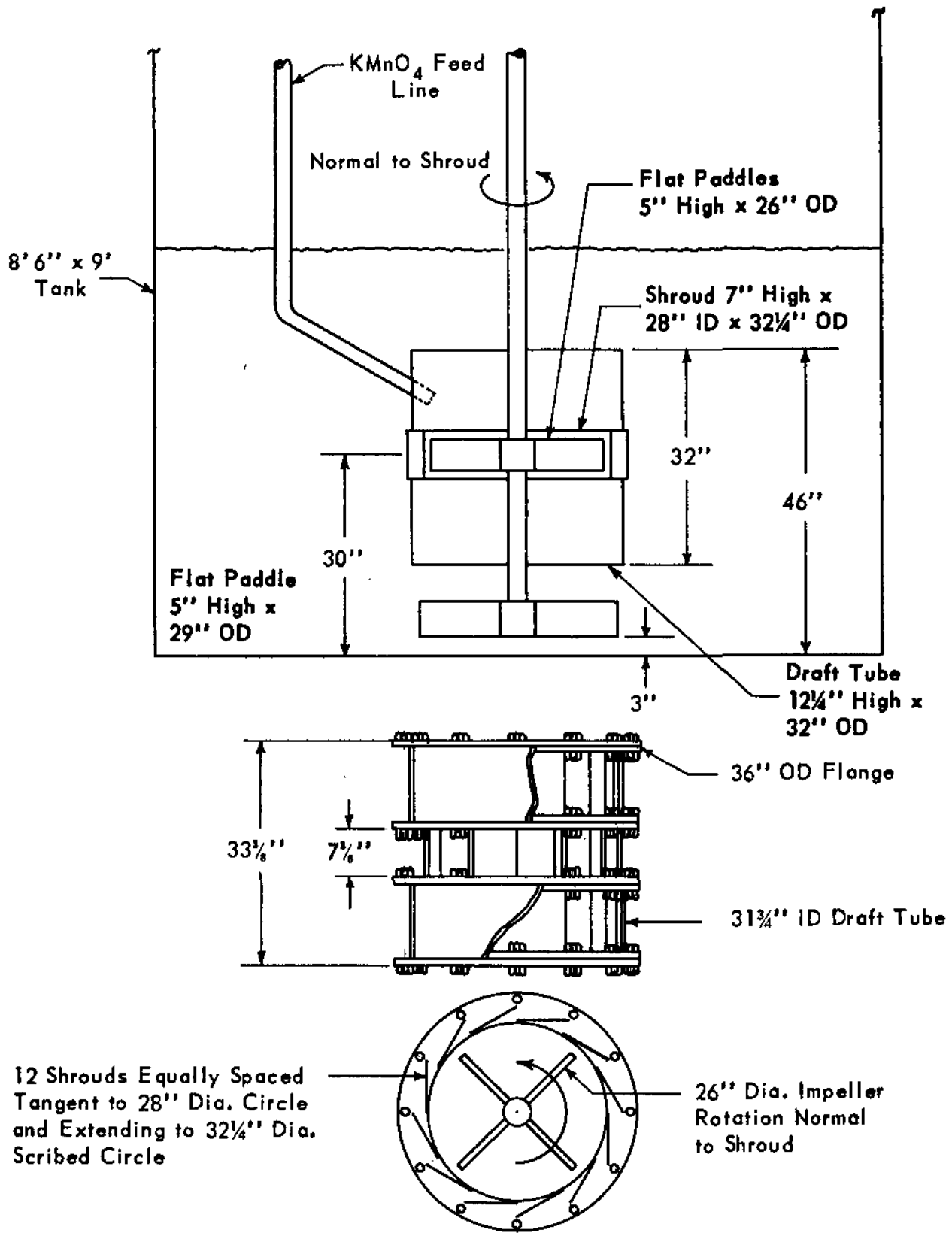

FIGURE 2 - DETAILS OF THE AGITATOR IN THE STRIKE TANK

\section{PROCEDURE}

The several variables studied which might affect preclpitate properties were; the solution temperature, agitator speed with and without the shroud, $\mathrm{KMnO}_{4}$ addition rate, and point of addition of the $\mathrm{KMnO}_{4}$. Laboratory studies were made to determine the effect of salt concentration and acidity. 
The procedure used for precipitation of the $\mathrm{MnO}_{2}$ is generally described as follows. The simulated dissolver solution, approximately 2000 gallons of $1.3-1.4 \mathrm{M} \mathrm{UO}_{2}\left(\mathrm{NO}_{3}\right)_{2}$ adjusted to $0.1-0.4 \mathrm{~N} \mathrm{HNO}_{3}$, was added to the strike tank. Sufficient $\mathrm{Mn}\left(\mathrm{NO}_{3}\right)_{2}$, about 85 pounds, was added, to leave a $15 \%$ excess after $\mathrm{MnO}_{2}$ precipitation. The solution was agitated throughout the precipitation step. Approximately 44 pounds of $\mathrm{KMnO}_{4}$, as a 5 weight per cent solution, was added at a rate of 4-20 pounds of solution per minute to the strike tank. The temperature of the strike tank was malntained at either 160 or $190^{\circ} \mathrm{F}$. In each run approximately 60 pounds of $\mathrm{MnO}_{2}$ was precipitated. The strike tank was subsequently cooled to $100^{\circ} \mathrm{F}$, and the solution transferred by jet to the centrifuge. This transfer was made at rates varying from 5 to 25 gallons per minute, but the rate was kept constant during any one run. The centrifuge speed was maintained at $1700 \mathrm{rpm}$. No simmer period was incorporated either after $\mathrm{Mn}\left(\mathrm{NO}_{3}\right)_{2}$ addition or after $\mathrm{KMnO}_{4}$ addition.

After completion of the centrifugation the remaining supernate was skimmed from the bowl. The cake was then subjected to five successive washes. In each wash approximately 25 gallons of $0.1 \mathrm{M} \mathrm{HNO}_{3}$, to prevent peptization of the cake, was sprayed against the bowl at about $600 \mathrm{psi}$. The resulting mixture was slurried by alternately rotating and suddenly braking the bowl. The cake was then recentrifuged and the wash solution skimmed from the bowl.

Following the last wash the cake was again slurried with $0.1 \mathrm{M} \mathrm{HNO}_{3}$ and, while still a slurry, jetted to a hold tank. This procedure was repeated three more times to rinse all cake from the bowl. The slurried solution from the centrifuge, containing approximately $10 \%$ by welght of $\mathrm{MnO}_{2}$, was recycled at 100 gallons per minute through the simulated waste header system shown in Figure 3 .

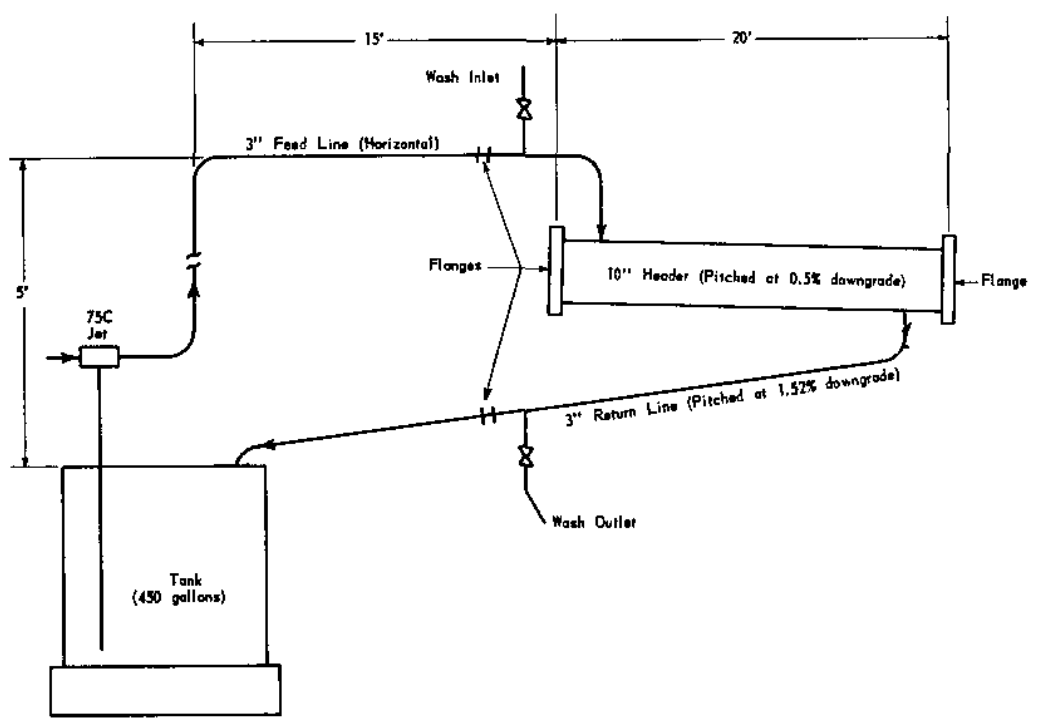

FIGURE 3 - MOCKUP OF WASTE HEADER 


\section{EXPERIMENTAL RESULTS}

The Appendix shows a summary of the runs made on large-scale equipment. In each run one or more variables were changed from previous runs to best determine the effect of each variable. The results from observations during the runs and from the data are summarized below:

1. A faster-setting precipitate, which can be fed to the centrifuge at five to $\mathrm{six}$ times the original process rate of $4.5 \mathrm{gpm}$, was produced by the addition of a shroud around the top agltator paddle and a line to feed the $\mathrm{KMnO}_{4}$ at the shroud. (Run 12)

2. The preclpitate when formed at $160^{\circ} \mathrm{F}$ at an agitator speed of $120 \mathrm{rpm}$ was as easily processed as that produced at $190^{\circ} \mathrm{F}$ at an agitator speed of $100 \mathrm{rpm}$. (Runs 1, 2, 3, and 9)

3. The cake volume was approximately doubled when the $\mathrm{KMnO}_{4}$ addition rate was increased from 5 to 20 pounds per minute with good agitation in each case. (Runs 7 and 8)

4. Decreasing the $\mathrm{KMnO}_{4}$ addition rate when striking with moderate agitation was not, by itself, sufficient to reduce the cake volume. (Runs 10 and II)

5. The decontamination factors, based on $\mathrm{UX}_{1}$ activity, were found to be similar (approximately 3) to those obtalned by the forward strike.

6. Tests in the semiworks and in the Savannah River Laboratory showed that the degree of turbulence of the $\mathrm{Mn}\left(\mathrm{NO}_{3}\right)_{2}$ solution in the zone to which the $\mathrm{KMnO}_{4}$ is fed and the feed rate of the $\mathrm{KMnO}_{4}$ are the two most significant variables affecting precipitate properties. (Figure 4)

7. The variables of temperature, acidity, and salt concentration investigated in the laboratory, had slight effect on the properties of the precipitate. (Figure 5)

The effectiveness of the wash procedure is controlled by two factors. The first is the volume of the cake which, when large, reduces the degree of dilution obtained by each fresh wash charge. The second factor is the completeness of supernate removal after each wash. In the semiworks test the skimmer was manually operated; therefore, in some washes more supernate was removed than in others, depending on the amount of cake being observed in the wash discharge. 

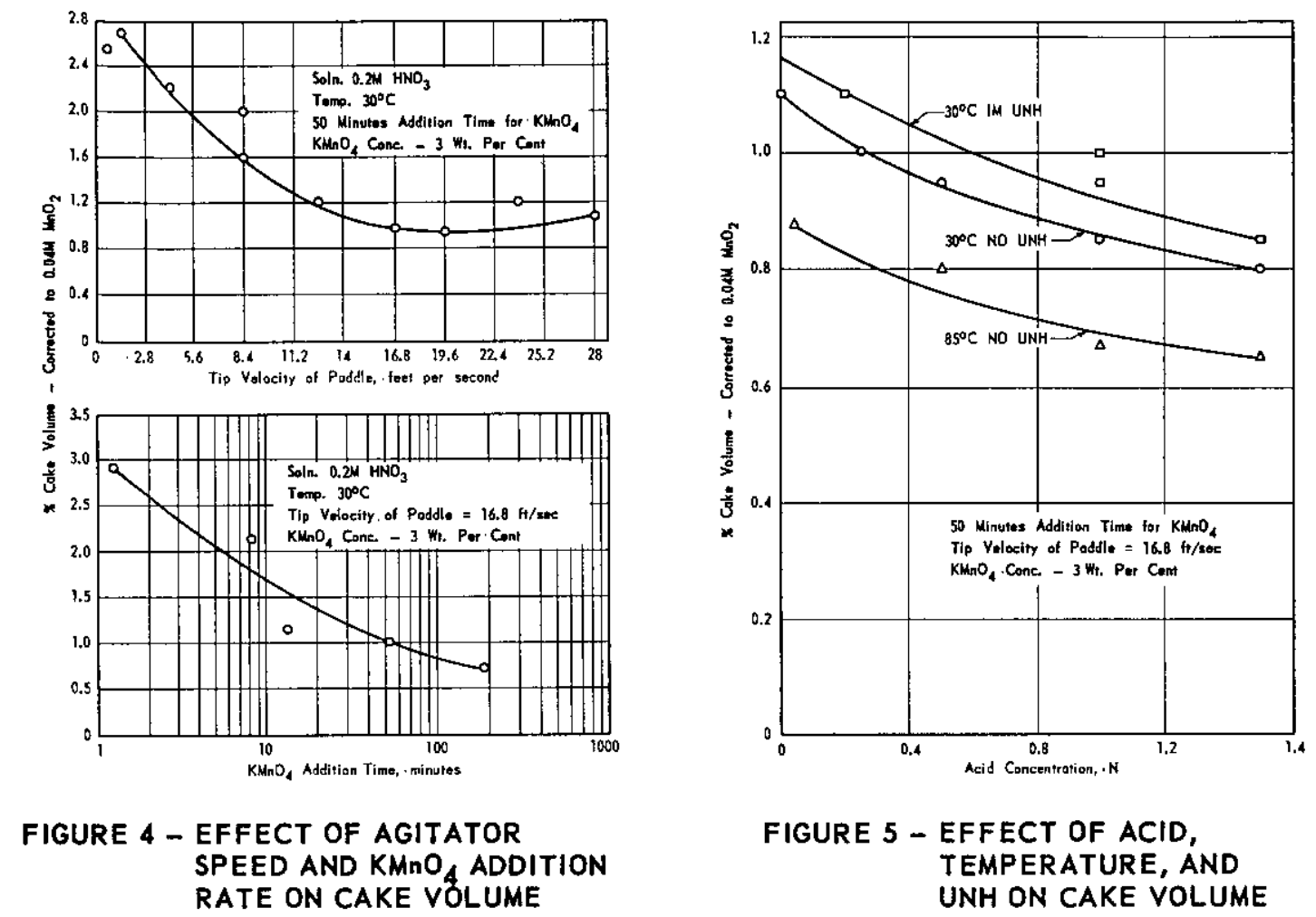

Figure 6 shows the different wash curves that are obtalned on essentially the same type cake. Since the modified procedure produces a more compact cake, the skimming operation can be more effective in removing supernate without removing any cake. An increase in wash efficiency is also obtained by the greater dilution of each successive wash solution. This increased efficlency is also shown in Figure 6 . The reduced volume of the cake not only permits higher capacity in the head end equipment but also yields the added advantage of improved cake washing. This washing improvement can be used either to reduce losses to the cake or to reduce recycle volume by reducing the number of cake washes. Fewer cake washes would also reduce the operation time cycle.

Three rinses were shown to be sufficlent to remove ali cakes from the bowl regardless of the cake properties. One exception was the removal of the double, 120-pound cake. Three rinses failed to remove all cake from the wall due to the excess cake volume and the greater degree of packing. Two or three further rinses would be necessary to rinse the bowl clean. 


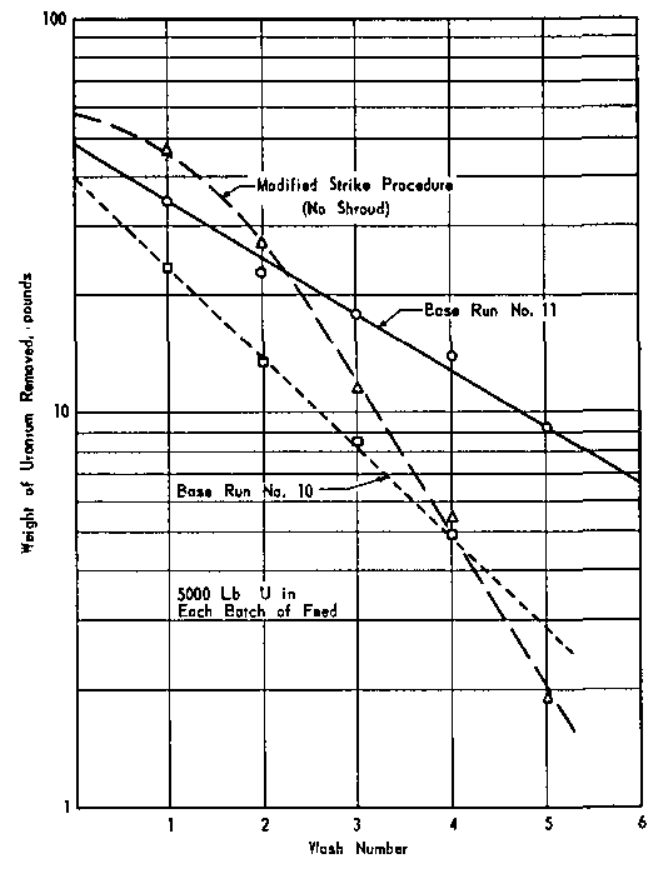

FIGURE 6 - EFFECTIVENESS OF WASHING

The uranium losses to the cake were determined by analysis of the slurried cake solution. The loss figures are shown in the Appendix. The variation in loss is attributed to the wash step and cake properties and is not affected by the cake removal procedure.

The test made to determine the behavior of the more dense cake when disposed of as a slurry through the simulated waste header showed no accumulation of $\mathrm{MnO}_{2}$ after several hours of recycling. Results were similar on both the dense and the more voluminous precipitates.

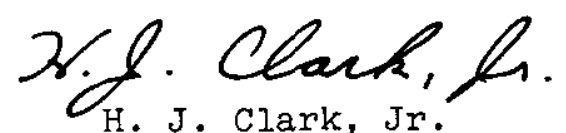

H. J. Clark, Jr.

Separations Engineering Division 


\section{BIBLIOGRAPHY}

1. Parkes, A. N., J. Reed, and R. M. Wallace, Purex Head-End Studies. E. I. du Pont de Nemours and Co., Alken, S. C. AEC Research and Development Report DP-69, 32 pp. (May 1954) (Confidential).

2. Grace, J. T., H. E. Henry, and D. G. Karraker, Precipitation of Manganese Dioxide. E. I. du Pont de Nemours and Co., Aiken, S. C. AEC Research and Development Report DP-346, 12 pp. (December 1958).

3. Hicks, H. G., C. G. McCormack, and W. E. Roake, Laboratory Demonstration of Redox Feed Head-End Treatment; Ruthenium Volatilization and Manganese Dioxide Scavenging. Hanford Atomic Products Operation, Richland, Wash. AEC Research and Development Report HW-22076. $61 \mathrm{pp.} \mathrm{(July} \mathrm{1951)} \mathrm{(Confidential).}$ 